\title{
TOWARDS A MORE ACCOUNTABLE EU - MISSION POSSIBLE?
}

\author{
Gergana RADOYKOVA
}

Assistant Professor, $\mathrm{PhD}$

Political Science Department, Faculty of Philosophy, Sofia University "St. Kliment Ohridski”

geri_radoykova@yahoo.com

\section{DOI:10.24193/OJMNE.2017.23.06}

\begin{abstract}
The European Union's uniqueness is very much related to its ever-changing nature. Now, when the European project is facing one of the biggest crisis in its history, it is inevitable that some changes will and shall occur. We are at a crucial phase of the development of the European Union. At a time of multiple global, economic, environmental and societal transformations and challenges European citizens expect the European Union to make a concrete difference in addressing the biggest of them.

The author believes that the main objective shall be bringing back the awareness and trust of the European citizens in the European project, in improving the accountability mechanisms of the European institutions, which are the key legitimizing factor of the EU decision-making process. The European Parliament, together with the national parliaments shall play a central role in this process.
\end{abstract}

Keywords: European Union, European Parliament, citizens' participation, awareness, accountability.

"A body of men, holding themselves accountable to nobody, ought not to be trusted by anybody" Thomas Paine, “The Rights of Man” (1791)

Over the past 60 years the European community and later the European Union has been in a process of constant development and transformation. Starting with the European Coal and Steel Community in the late 50's it is continuously growing - in geographic terms, but most importantly - in the amount of competencies and influence in different policy areas 
- from the single market and monetary union to immigration, judicial and policy cooperation, including common foreign policy.

Needless to say, expanding the powers of the EU led to growing of the expectations of the citizens of the Union. It has been an old tradition to hold national governments responsible for bad economic conditions - now the EU is often shouldering most of the blame when things go not as expected.

The most important thing, however, is that the relation EU-citizens is damaged. The European Union is currently facing one of the most serious crises in its existence, which can be probably described better with the sentence "Brussels, we do not trust you". Still, citizens' participation is remarkably important for each democratic system, so as for its democratic legitimacy as its cornerstone.

The trust of citizens in the democratic institutions has been fading. One of the most obvious effects is the ever decreasing rate of the voting attendance of the European citizens. It endangers the legitimacy of the European Union as its political institutions are being questioned and doubted, and the national governments are often under the pressure of international bodies.

The reaction of the EU to the economic and financial crisis, the migration crisis and the terrorist threat financial crisis, shows it is a must for the EU to prove being capable to learn from its mistakes and to move forward to an inclusive participatory democracy - where the voice of the people is not just heard but also considered during the decision-making process.

\section{The salience of democratic accountability}

Here, in my opinion, the question of democratic accountability is central. To what extent are citizens capable of holding the public institutions to account for their actions? The answer is quite simple: the most important thing is to exist a "point of intersection" between the level of political decision-making by the actor (politicians) and the level on which the forum (citizens) can demand accountability from those whom they have previously empowered through elections (Curtin, 2010). This is quite a difficult task in a multilevel system of governance, such as the EU. A crucial question is whether citizens can understand 
who is responsible and assign responsibility and accountability accordingly (Allerkamp, 2010). The capacity and willingness of citizens to take active part in the political debate and the decision-making process, and to urge the politicians to give account for their actions, is undoubtedly the hallmark of good governance and real democracy (Hood, 2012).

When we elaborate on the important topic of accountability in politics, it is wise to start with an attempt for definition. What does accountability mean and stand for? How can it be measured? Why do we bother about accountability in politics at all?

Accountability is considered and generally accepted to be a "golden concept", which is supposed to be a key component and one of most important features of each democratic governance. That means that in most of the cases accountability has mainly positive connotations. Why? There could be at least two reasons. First and foremost, public institutions are obliged to explain the decisions they make on behalf of the electorate and also to give clear account about the way in which they spend public money. Second, the adjective "accountable" is often associated with transparency, reliability and truthfulness.

In reality accountability is a very broad concept, which serves as an umbrella for quite different concepts. There is no doubt, however, that accountability is the key legitimizing factor of the public institutions.

We choose to follow the definition of Mark Bovens and Deirdre Curtin, according to which accountability is a social relationship between an actor and a forum, in which the actor has an obligation to explain and to justify his or her conduct, the forum can pose questions, and the actor may face certain consequences (Bovens, Curtin, Har, 2011). Analyzing accountability from that perspective gives the opportunity to study the whole chain of interactions between citizens (as the forum) and public institutions (as the actor), as well as the positive and negative aspects of accountability arrangements.

Each accountability relationship should consist of at least three main elements. First of all comes information. It is very important that the actor regularly informs the forum about his conduct and political decisions, as well as about concrete procedures and accomplished results. But simply informing the forum (the citizens) does not only consist of providing detailed data to the general public. It also includes the obligation for the forum to explain and justify its conduct. 
The second face is the debate. After receiving the information, the forum should have the possibility to ask any question, concerning this information and the legitimacy of the decisions. The forum has the obligation to give an answer to all the questions. That is why the term "accountability" is often equalized with "answerability", but the latter is actually one of the "ingredients" of accountability.

Third and most important, the forum can pass judgement on the justification of the actor. The judgement could be positive, of approval, or negative. And if there is enough evidence of misconduct the forum may face sanctions. It is the possibility of sanctions that makes the most important element of an accountability relationship.

There are different opinions among researchers, however, whether sanctions are actually an element of accountability. The term "sanction" itself is quite formal and legal and has quite negative connotations. It excludes forums of accountability who do not have the authority to formally impose sanctions but their opinion still matters a lot. That is the reason why in this context we prefer to remain neutral by saying that the actor may face consequences for its behavior, rather than sanctions.

There is a common practice to use the term "transparency" instead of "accountability". The above mentioned definition, however, shows us that transparency is not enough to cover the constitutive elements of the accountability relationship. Transparent government, freedom of speech and information are just important prerequisites for accountability, especially when it comes to providing information. Transparency, however, lacks something very essential - it does not involve scrutiny and monitoring from the forum. While accountability implies mainly the obligation for the actor to justify political decisions and actions, transparency stands for the type of behavior that makes the actions of the forum visible for the observers (Hood, 2010).

It is also important to distinguish accountability from participation, openness and responsiveness. It often happens, especially in the official documents at EU level that accountability is related to issues of representative deliberation. Here a very important detail seems to be forgotten - the actors (politicians) are to give account to the forum (citizens) after they act, so the essence of accountability is retrospective. Responsiveness, openness and deliberation are very important for enhancing legitimacy, but they do not form accountability 
and are more likely to be a prerequisite for it. What is missing is the element of sanction and consequences, good or bad, for the actor.

We have to admit, however, that the difference between retrospective accounting and active policy making is quite thin at times. It makes sense that the actors should give account for their decisions and for their participation in the decision-making. Accountability is not only about ex post monitoring and evaluation, it also about prevention. Political decisions and the behavior of the actors should be adjusted and bettered through accountability.

Accountability is also often identified with control. Some researchers and politicians would even put a sign of equality between them. What seems to be forgotten here is the following definition: "An agent is accountable to a principal if the principal can exercise control over the agent" (Lupia, 2003). So accountability is a form of control but not all forms of control are actually mechanisms for accountability.

And last, but not least - there is a difference between accountability and responsibility. Responsibility as a virtue demands an answer of the question "What is right to be done?" It also implies trust, prudence, stability and erudition. That is why responsibility is not equal to accountability, it creates and strengthens accountability.

If we choose to follow the famous Lincoln definition for "government of the people, by the people for the people", we should conclude that legitimacy has two faces. Input legitimacy stands for government by the people, while output legitimacy is based on the concrete results and is about government for the people. When we discuss and evaluate the results, we can clearly observe the importance of accountability for legitimizing the work of the public institutions.

\section{Representative vs. direct democracy in the EU}

If we look at the institutional structure of the European Union, we will see that it is based on representative democracy, putting more emphasis on participation in the last decade. The European Union emphasizes and encourages citizen participation and is constantly trying to set up a proper legal framework in order to strengthen its democratic legitimacy. The Treaty of Lisbon sets that: 
1. The institutions shall, by appropriate means, give citizens and representative associations the opportunity to make known and publicly exchange their views in all areas of Union action.

2. The institutions shall maintain an open, transparent and regular dialogue with representative associations and civil society (TEU, 2009).

So this is the legal basis for bringing the European Union closer to its citizens, for making it more transparent, understandable, and "digestible" for the citizens.

An example of a typology based on citizen involvement is the classic model of Arnstein. According to Arnstein can be demonstrated by a ladder - its rungs represent the different levels of participation. She defines eight rungs starting from manipulation through consultation to citizen control, concluding that citizen participation is citizen power (Arnstein, 1969).

The responsibility to decide is delivered over to the elected individuals, who undertake the responsibility this representative role. It is a system of indirect citizens' control, where the people express their opinion, influence the decision-making process through their elected representatives who exercise political authority. In the case of the European Union it means an orientation towards providing a more significant role for the European Parliament and involving the national parliaments of the member states in the decision-making process.

The European Union has developed a new form of interaction between its citizens and the institutions of the Union. One of the most important proposal was the establishment of the European Citizens' Initiative in 2012, which aims to urge citizens' involvement in the shaping of EU policies. Unfortunately, 5 years from the launching of ECI, it proved to be a disappointment, rather than success.

According to the European Commission's Guide (European Commission, 2011) the European Citizens' Initiative is a big step towards a wider involvement of the European citizens in forming the EU's legislative system. It enables 1 million European citizens (from at least seven countries of the EU) to propose a legal act in areas which are within the competence of the European Commission The initiative has one year to collect the necessary signatures, in the next phase the Commission examines and decides how to act on it. 
In my opinion the initiative was a good idea as a whole, but in practice it brings up some difficulties. Compared to the total population of the European Union ( 500 million) the needed minimum number of signatures for starting an initiative makes only its $0,2 \%$. So it might turn into a good opportunity for the lobbyists who can use it to their advantage. However the main aim of the ECI is to give a voice to the ordinary citizens, not to certain interest groups, good in persuasion. If the process is not simplified and not wellcommunicated, then citizens will not take advantage of the option. Besides, the European Union should provide a fast and satisfactory feedback about the outcome of the actual initiatives in order to maintain the connection with its citizens. The ECI should be simplified and strengthened so it can be a useful tool for citizens' awareness and participation.

\section{Advantages and risks of citizen participation}

According to Sutton Trust findings (Sutton Trust, 2006) increasing the number of people who are actively engaged in democratic process is priority for the efficient functioning of the EU. Participation gives the citizens an opportunity to express their desires, aims, so the decisions can be more incisive, and also the accidental conflicts between different groups can be prevented. Moreover, local people can improve their skills, develop their abilities, and their willingness to consensus and to achieve long-lasting solutions to any local problem. In addition, participation increases social cohesion between local people, as it increases the level of trust and the sense of belonging to the territory.

Sutton Trust research also reveals the disadvantageous side of citizens' participation. Creating awareness and involving citizens in decision-making leads and aims toward equality. If the number participants is narrow, lacking an efficient selection method, the democratic control is not actually fulfilled. Besides this, participation in the last year has proved to be a strong weapon for populists all over the European Union. It can also be a very time-consuming for achieving consensus. Citizen participation is also criticized as naive, unrealistic, lacking broad representation, and that citizens are primarily following their personal interests, and not the public good (Callahan, 2007).

Citizens need to feel motivated to urge to participate in the decision-making process if they see the positive benefits in their everyday life from doing so. People also feel motivated 
when they have some aspect of their life or welfare threatened and when they have a better understanding of a political issue or situation.

Back in 2001 the European Commission presented a White Paper on Good Governance proposing "openness" and "participation" by involving the civil society (European Commission, 2011). Still The White Paper focused mostly on involvement of specific interest groups, civil organizations, and not on the ordinary citizens.

The year of 2013 was proclaimed as the "European Year of Citizens", aiming to strengthen "active citizenship", and to involve the ordinary citizens in dialogues, and in the work and policy-making of the EU institutions. Still what truly happens is that the EU stands for creating a direct relationship with its citizens but during circumvents the governments of its member-states, instead of collaborating with them.

In March 2017, the European Commission launched a White Paper on the Future of Europe. Discussions about the EU's 'democratic deficit' have been going on for decades, so the issues the White Paper brings up are not new. However, for the first time there seems to be a definite recognition of the need for change. The Commission's discussion paper is remarkably candid about widespread public distrust of Brussels, stating for example that “citizens' trust in the EU has decreased in line with that for national authorities" (White Paper on the Future of Europe, 2017). Around a third of citizens trust the EU today, when about half of Europeans did so ten years ago. Overcoming this mistrust issue will not be easy, since: "Communities are not always aware that their farm nearby, their transport network or universities are partly funded by the EU".

The White Paper emphasizes the importance of facing expectations as being critical for future success of the European project. Where the Commission builds up expectations for economic growth and cross-border harmony driven from Brussels, it truly and inevitably makes itself vulnerable to attacks. When suggesting faster and stronger integration as one option (the fifth and final), the Commission notes there is the risk of alienating parts of society which feel that the EU lacks legitimacy or has taken too much power away from national authorities. On the other hand, the Commission states firmly that going back to the single market alone is not a good (second) option, etc. 
Problems originate from the citizens who are uninformed about their rights and possibilities what they possess by being citizens of the EU. In my opinion is important to fill the term "European citizenship" a real content besides its symbolic interpretation by informing the citizens with the help of mass media.

Moreover, there are various legal tools for citizens to petition or make complaints against the decisions of the EU, but these opportunities are not used very often - often for red tape considerations. The EU are complex and time-consuming nature of these legal tools, and also the ignorance of citizens about their rights.

The EU creates all the tools for the citizens' involvement, but still it may somehow try hinder this participation. Public officials may state that citizens are incompetent, while citizens, on the other hand blame the officials and institutions for not being invited to truly participate in the process - proving the saying that "ninety percent of politics is deciding whom to blame (Greenfield, 1996).

If citizens are not involved in the decision-making process from its beginning, they are usually less supportive. Citizens should be encouraged by feedback of the completed projects. People as a whole are more dedicated to participate in any initiative if they see it as their own and experience the betterment in the life of their own locality. The civil society should be strengthened to support democracy, in order to stop the declining trust of citizens in their politicians. The European Union and the members-states should encourage more voluntary activities and social connectedness which would represent "happening of participatory democracy".

The citizens of post-communist member-states, such as Bulgaria for example, show a diverse willingness to participate in the decision-making process both on European and national level.

\section{The role of media and information}

In the very complex system of the EU information matters a lot. Media has become a very powerful communication channel which can unfortunately be used as a tool to manipulate the masses. Media can prove to be very influential, convincing messages for the people, who are many times unaware of the fact that they are influenced. The European 
Union often uses the help of the media to inform citizens about its achievements, initiative. The shift towards a participatory democracy and the freedom of speech involves the risks of demagogic and populist interventions which must be controlled in order to preserve its legal pursuit. The new possibilities given by modern technologies should be utilized, but wisely.

People who are more politically aware are also able to assign responsibility to the EU correctly. It is interesting that people who read papers with a lot of EU coverage are prove to be more competent than those who rely on television coverage - it is very often for television to simply prime the citizens to think more about the EU (Hobolt, Tilley, 2014).

\section{Conclusion}

In the EU, there are two contradictory trends which are simultaneously presented: globalization and centralization. While certain decisions are moved from national to EU level taking away some national sovereignty, on the other hand the principle of "subsidiarity" is also emphasized, which refers to solving problems on lower levels and supporting community activity. The Union, therefore, on one hand enhances citizen participation by using deliberative methods to involve stakeholder, but on the other hand widens the gap between its citizens and the policy-makers.

At the time of a legitimacy crisis of the EU, much attention should be paid on fostering a comprehensively efficient citizen participation. It means creating a platform which is transparent and easily available for ordinary citizens or for civil organizations. Through this they can visibly participate in the public debates and express their opinion.

After looking over the different factors and influences which pull back the establishment of a legally operating participatory system, the following observations can be specified:

- Civil participation and awareness is crucial for the legitimacy of the European Union

- The legal basis for citizen participation is adequate, the obstacles mainly appear in putting them into practice

- A feedback is needed about the outcome of any initiative on EU level, that implies citizen participation

- A two-way communication is needed between the citizens and the authorities 
- Media should be utilized in a fair way by the EU - to inform citizens about the results and the possibilities and not to manipulate them

Citizens should start to care not only about what the EU and its institutions can do for them and their countries, but also what the same EU institutions can do for the European project as a whole. As the President of the European Council stated recently - "United we stand, divided we fall” (Tusk, 2017).

\section{Bibliography}

- ALlERKAMP, D. (2010). Who Sets the Agenda? - How the European Council and the Team Presidencies Are Undermining the Commission's Prerogative - ECPR SG EU Porto, Portugal, http://www.jhubc.it/ecpr-porto/virtualpaperroom/159.pdf, [Accessed 03/09/2017].

- ARNSTEIN, S. (1969). A Ladder of Citizen Participation. In: AIP, Vol. 35, No. 4, July 1969, pp. 216-222, http://www.tandfonline.com/doi/abs/10.1080/01944366908977225, [Accessed 13/09/2017].

- BOVEns, M./ CURTIN, D./ HART, P. (eds.) (2010). The Real World of EU Accountability. What Deficit? Oxford: Oxford University Press.

- BOVEnS, M./ SCHILlERMANS, T./ HART, P. (2008) Does Public Accountability Work: An Assessment Tool? In: Public Administration 86/1, pp. 225-242, http://academic.udayton.edu/RichardGhere/org\%20theory\%202009/major\%20readings/B ovens\%20Schill\%20performance.pdf. [Accessed 08/09/2017].

- CALlaHAN, W. A. (2007) Future Imperfect: The European Union's Encounter with China (and the United States). In: Journal of Strategic Studies, Vol. (4-5), pp. 777-807 (ON), $\quad$ https://rd.springer.com/article/10.1007/s12140-009-9104-1?no-access=true. [Accessed 13/09/2017].

- CURTIN, D. (2009) Executive Power of the European Union. Law. Practices and the Living Constitution. Oxford: Oxford University Press. 
- CURTIN, D./ MAIR, P./ PAPADOPOULOS, Y. (2012) Accountability and European Governance. Routledge, USA and Canada: West European Politics Series.

- CURTIN, D./ MEIJER, A. (2006) “Does Transparency Strengthen Legitimacy? A Critical Analysis of European Union Policy Documents”. In: Information Polity, 11:2, pp. 109-22, https://papers.ssrn.com/sol3/papers.cfm?abstract_id=1434862, [Accessed 30/09/2017].

- FOLlESDAL, A./ HIX, S. (2006) "Why There Is a Democratic Deficit in the EU: A Response to Majone and Moravcsik”. In: Journal of Common Market Studies, 44:3, pp. 530 - 560, https://papers.ssrn.com/sol3/papers.cfm?abstract_id=1682094, [Accessed $15 / 09 / 2017]$.

- HOBOLT, S./ TILLEY J. (2014) Blaming Europe? Responsibility without Accountability in the European Union. Oxford: Oxford University Press.

- KARLSSON, C. (2009) Holding Treaty Reformers Accountable: Any Progress? In: GUSTAVSSON, S./ KARLSSON, C./ PERSSON, T (eds.) The Illusion of Accountability in the European Union. London: Routledge, pp. 67-82.

- LUPIA, A. (2003) Delegation and its Perils. In: STROM, K./ MULLER, W./ BERGMAN, T. (eds). Delegation and Accountability in Parliamentary Democracies. Oxford: Oxford University Press.

- MORAVCSIK, A. (2002) In Defence of the Democratic Deficit: Reassessing Legitimacy in the European Union. In: Journal of Common Market Studies, 40/4, pp. 603-624, Available at: https://www.princeton.edu/ amoravcs/library/deficit.pdf, [Accessed 13/09/2017].

- SETAlA, M./ SCHILlER, T. (2012) Citizens' Initiatives in Europe, Palgrave, Macmillan.

\section{Official documents}

- Treaty of Lisbon amending the Treaty on European Union and the Treaty establishing the European Community, signed at Lisbon, 13 December 2007, Official Journal of the European Union, 2007/C 306/01, http://eur-lex.europa.eu/legalcontent/BG/TXT/?uri=CELEX:12007L/TXT, [Accessed 12/09/2017]. 
- Regulation (EU) No 211/2011 of the European Parliament and of the Council of 16 February 2011 on the citizens' initiative (Consolidated version 28/07/2015), http://eurlex.europa.eu/legal-content/EN/TXT/PDF/?uri=CELEX:02011R0211-

20150728\&from=EN. [Accessed 08/09/2017].

- EUROPEAN COMMISSION (2001), White Paper on Good Governance, http://eurlex.europa.eu/legal-content/EN/TXT/?uri=LEGISSUM:110109, [Accessed 01/09/2017].

- EUROPEAN COMMISSION, (2011) Guide to the European Citizens' Initiative. Available at: https://publications.europa.eu/en/publication-detail/-/publication/ac66340b5355-4df6-9095-93ac91dadd18/language-bg, [Accessed 07/10/2017].

- EUROPEAN COMMISSION (2017), White Paper on the Future of Europe - Reflections and Scenarios for the EU27 by 2025, https://ec.europa.eu/commission/sites/betapolitical/files/white_paper_on the future_of_europe_en.pdf. [Accessed 21/09/2017].

- EUROPEAN COUNCIL (2017), Letter by President Donald Tusk to the 27 EU heads of state or government on the future of the EU before the Malta summit, http://www.consilium.europa.eu/en/press/press-releases/2017/01/31-tusk-letter-futureeurope/. [Accessed 19/09/2017]. 